\title{
A Sustainable BSC-IT based Framework for Assessing the Strategic Impacts of Green IT Initiatives
}

\author{
Luis Ruiz ${ }^{*} \cdot$ Jeong-Sun Park \\ ${ }^{*}$ Dept. of Industrial and Management Engineering, Myongji University \\ 그린IT 이니셔티브들 전략적 영향들을 평가하기위한 지속가능한 \\ $\mathrm{BSC}-\mathrm{IT}$ 기반 프레임워크 \\ Luis Ruiz ${ }^{*}$ 박 정 선* \\ *명지대학교 산업경영공학과
}

\begin{abstract}
We don't have time to waste, time is running, and the global warming is an issue that concerns to all of us. Information technology, which on a global level is responsible for $2 \%$ of emission of greenhouse gases.

However, the remaining $98 \%$ is seen as an opportunity for IT to help our planet, our companies and our society. The purpose of this paper is to analyze green information technology (IT) initiatives and their strategic impact. And to have done this, we develope and create a very useful balanced-scorecard framework to explain, understand, and identify the direct and indirect contribution of green IT initiatives. The green IT evaluation framework, called here a sustainable green IT balanced scorecard, integrates the four BSC-IT perspectives with the Zuboff's automate/informate goals of information systems and the contribution of the sustainability (economic, social and environment). This study also seeks to answer the following questions: 1) what are the driving forces for implementing green IT initiatives? 2) How can an analytical framework be built to systematically analyze the benefits and strategic contribution of green IT initiatives? And 3) how green IT initiatives impact the strategic goals of a firm and how they can contribute to the triple bottom line? The framework demonstrates to be useful as a management tool to hopefully integrate environmental and social management with the general management of a company. Besides, the strategy map and measures for each cell of the framework are provided.
\end{abstract}

Keywords : BSC, BSC-IT, sustainable, measures, green IT initiatives

\section{Introduction}

The balanced scorecard concept introduced by Robert Kaplan \& David Norton(2006) holds a fundamental premise that states that the evaluation of a firm should not be restricted to a traditional financial evaluation but should be complement with measures concerning customer satisfaction, internal processes and the ability to innovate. By applying a series of specific objectives, measures, targets and initiatives to each perspective, this "Balanced" method should guarantee future financial result and drive organization on the road to its strategic goal while keeping all four perspectives in balanced.

\footnotetext{
† 교신저자: 박정선, 경기도 용인시 남동 산 38-2 명지대학교 산업경영공학과

H·P: 010-3638-6453, E-mail: jspark@mju.ac.kr

2012년 10월 20일 접수; 2012년 12월 5일 수정본 접수; 2012년 12월 13일 게재확정
} 
The balanced scorecard can be applied to the IT function and its processes. The tool has evolved in design, complexity and content since the mid-1990s (Cram, 2007). The IT BSC has also been adopted as the base of specific IT Scorecards, like human resource information systems, enterprise resource planning (Chand et al, 2005), and customer relationship management systems.

This paper illustrates the applicability of the IT balanced scorecard to green IT initiatives and derives new valuation frame work for discovering and defining green IT initiatives success measures that impact the business objective, organization's strategies and the environment.

To address the bottom line of the sustainability (economy, environment and social), we develope a very useful 12 cells framework to explain, understand and identify the direct and indirect contribution of green IT initiatives.

Instead of adding a new perspective for the classical IT-BSC, the present paper suggests to assess each of the four perspectives along the next three themes of; automate/informate, human capital benefits and natural resource benefits.

\section{Review of the relevant literature}

In this paper, the empirical study is based on the material searched through internet in different search-engines, databases like IEEE, Science-direct, etc. press releases, business wires of companies involved in green IT initiatives, etc. The study is also based in papers, publications and books.

The function of the balanced scorecard has been examined in the environment of IT and information systems. One of the best acknowledged versions of the IT balanced scorecard is the one developed by Grembergen \& Bruggen (1998). The proposed four perspectives: The User Orientation perspective represents the use restimation of IT; the Operational Excellence perspective represents the IT processes employed to develop and deliver the applications; the Future Orientation perspective represents the human and technology resources needed by IT to deliver its services, and the Business Contribution perspective captures the business significance or the IT investment. In Grembergen \& Saull (2001), they also pointed up the application of their IT balanced scorecard model for a Canadian Financial group.

Radhika et al (2011) noted that no analytical framework existed to examine recent green IT initiatives. Wati \& Koo (2011) introduced a green IT balanced scorecard as a strategic IT management system. Nonetheless, until this stage, no body addresses the IT balanced scorecard to integrate environmental and social dimensions into the existing BSC and use as a framework for assessing green IT initiatives. In our judgment, Radhika's framing faulty does not contain outcome measures (lagging indicators), performance drivers (leading indicators) or neither cause \& effects relationship.

And according to Kaplan \& Norton (2006), those measures and relationships are the bases to generate a balanced scorecard.

\section{Green IT initiatives and findings}

Greening by IT initiatives patterns, the most popular embraced; the use of RFID, tele-presence, paperless solutions, print efficiency, logistic management software, assets-tracking systems, $\mathrm{e}^{-}$waste management, etc.

\subsection{RFID Initiatives findings}

The initiatives showed that RFID is a technology that can help business to generate revenue, create new commercial opportunities and improve environmental responsibilities. For example, by accurately tracking a perishable item and preventing its spoilage, RFID can save energy in operations ranging from growing and harvesting to packaging and refrigeration (Bose \& Yan, 2011). Many of the RFID projects, were in phase of development, and those already finished were finished recently, so RFID for green IT is just becoming popular. Another characteristic of the RFID case studies is that they're all from USA or Europe. The range of RFID application vary depending on project's nature and industry, but the predominance initiatives focused on using RFID for recycling, sensing, and asset tracking. 


\subsection{Tele-Presence video conference Initiatives findings}

According to the analysis of the case studies, tele-presence initiatives are driven by economic benefits, companies that wanted to lower traveling cost, found not only an economical reward but also important benefits such as: Reduction of unproductive time, acceleration of decision making, improving and boosting the collaboration across multiple global business and improving quality of life while reducing carbon footprint. The tele-presence projects are also becoming popular, but are still expensive, other initiatives related with tele-presence are videoconferencing, and telecommuting.

\subsection{Paperless and print management Initiatives findings}

Companies are realizing that digital paper and efficient printing generate not only profit but security, efficiency, and less $\mathrm{CO} 2$ emissions. The day that we will see a replacement for the paper is perhaps far away, but many business are trying to create a less-paper world. Companies from different industries are discovering ways to cut paper waste. According with the case studies, the paperless initiatives were driven in most of the cases by boosting efficiency and saving cost. Documents digitalization allowed companies to store huge data, fast searching (saving time), etc.

Many of the paperless initiatives use electronic documents management software, for digitalization, sharing, and even allowing electronic (approvals, request, signatures, etc). Paperless initiatives thus helped companies to save in paper, printing, traveling, space, etc. In the case of print management initiatives, the general patterns were based on the replacement of old stand-alone printers, for new energy-efficient network printers with default double-side printer and software that requires users to confirm a print job.

\subsection{Logistic management software Initiatives findings}

According to the green IT projects, the logistics management software initiatives were motivated for financial and environmental reasons. The rise of the fuel prices forced companies to find ways to cut transportation costs. As a result, initiatives oriented to improve the transportation-distribution networks were based on applications that generate better routers or distribution networks. The decrease in transportation resulted in reducing fuel consumption and $\mathrm{CO} 2$ emissions.

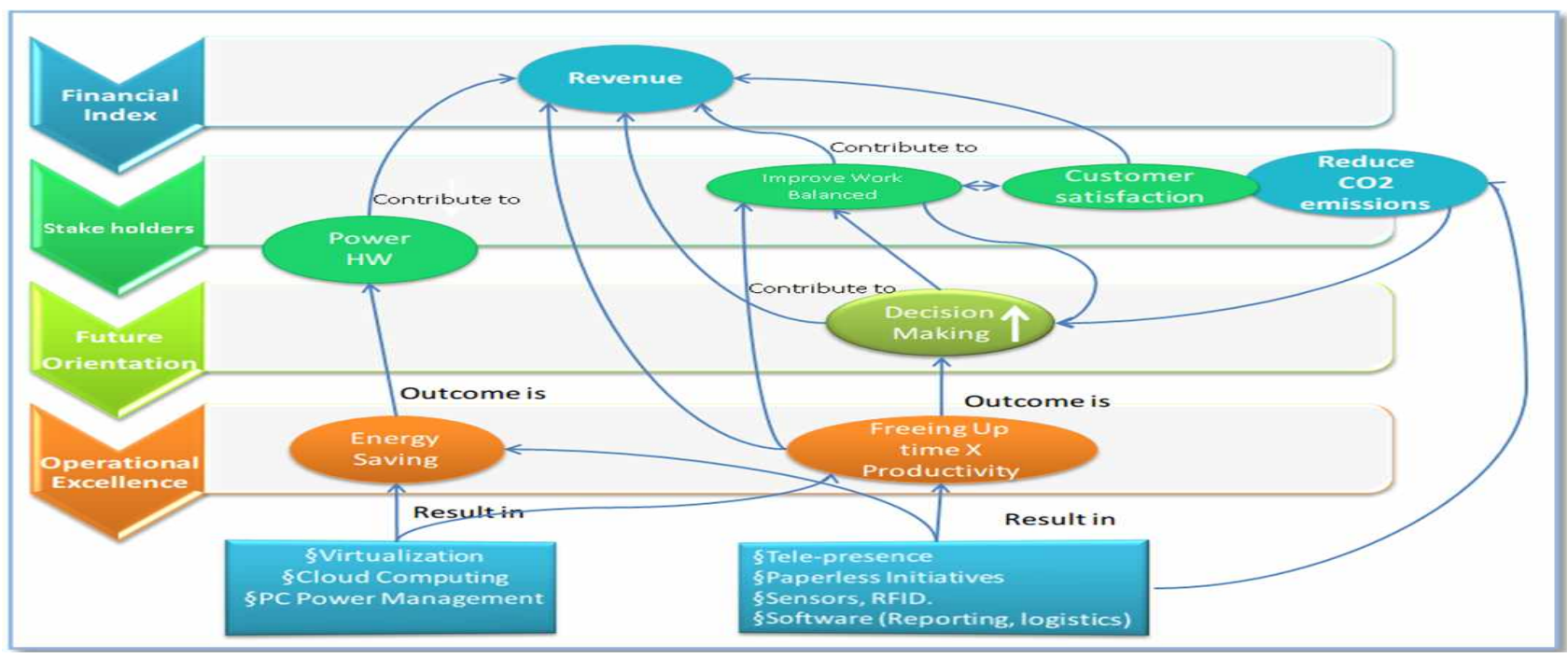

[Figure 1] Strategic maps 
4. The impact of green IT initiatives in the perspectives

The following description quotes six examples of the announcements. We identify them here by the company mentioned in the newswire, case study report, and list them with dates and URLs in Table 1.
The case studies show that the Green IT initiatives also: Affect the financial outcomes Impact the efficiency of the internal process operations - Impact the stakeholders orientation Generate innovation and opportunities to learning and be trained - Impact the environment and the society. Some examples are shown in the strategy map of Figure 1.

$<$ Table $1>$ Some examples of Green IT initiatives

\begin{tabular}{|c|c|c|c|}
\hline Company \& Source & Announcement Title & Date & URL \\
\hline RecydeBank & $\begin{array}{c}\text { Texas Instruments and Recy칟Bank Make an } \\
\text { Environmental Difference - One RFID Tag at } \\
\text { a Time }\end{array}$ & May -08 & $\begin{array}{l}\text { http://www.ti.com/rfid/docs/manuals/casestudies/RFID_Re } \\
\text { cycleBank_Case_Study_2008.pdf }\end{array}$ \\
\hline Nestle Italy & $\begin{array}{l}\text { Nestle Italy Finds RFID Brings ROI for Ice } \\
\text { Cream }\end{array}$ & April-08 & http://www.rfidjournal.com/article/view/4017/ \\
\hline $\mathrm{DHL}$ & $\begin{array}{l}\text { DHL Says Its SmartTrucks Save Money, Time } \\
\text { and } \mathrm{CO} 2 \\
\end{array}$ & Sep-09 & http://www.rfidjournal.com/article/view/5261 \\
\hline Procter \& Gamble & $\begin{array}{l}\text { Procter \& Gamble Transform the Way } \\
\text { Business is Done }\end{array}$ & Nov -09 & $\begin{array}{c}\text { http://www. 챠내.com/web/DE/cusconnect/2010-01/media/ } \\
\text { External_CaseStudy_Procter_Nov2009.pdf }\end{array}$ \\
\hline U.S Postal service & $\begin{array}{l}\text { U.S. Postal Service taps optimization software } \\
\text { to slash transportation costs }\end{array}$ & Apr-09 & $\begin{array}{l}\text { http://www.infoworldcom/d/green-it/us=postal=service=ta } \\
\text { ps=optimization-software=slash-transprotation }{ }^{-} \text {costs }-261\end{array}$ \\
\hline Niagara Catholic School & $\begin{array}{l}\text { Niagara Catholic School District turn to e-docs } \\
\text { to cut paper and }\end{array}$ & Apr-po & $\begin{array}{c}\text { http://dicushare.xerox.com/pdf/niagara_infoword_article_08 } \\
\text { _06_09.pdf }\end{array}$ \\
\hline
\end{tabular}

\section{Derivation of the framework}

The cases studies show a huge opportunity to address environmental/social issues while generating revenue and improving business process. However, there is not a clear framework to assess them. To generate a balanced scorecard, Kaplan \& Norton (2006) asserted that a balanced scorecard should emphasize financial outcomes, additionally, the scorecard should include measures critical to the success of the unit's established strategy. Since one of the purposes of the balanced scorecard is to discover and define a set of measures that enable management to understand the state of the organization in order to control and manage it. In other words, it is needed a framework that systematically guides the identification and selection of the green IT success measures. We now attempt to define a sustainable IT-Balanced scorecard based framework that will guide the identification and selection of key green IT success measures.

Adapting and configuring Grembergen's BSC-IT framework to a sustainable IT balanced scorecard appears to be more proper than Radhika's approach for building a sustainability balanced scorecard for assessing green IT initiatives.

Nevertheless, Grembergen's approach requires building cascading balanced scorecards from green IT initiatives level, to the IT department level, to the organizational level in order to link the sustainability IT balanced scorecard framework to the organizational business objectives. This puts the design of sustainable IT scorecard within the perspective of building the organizational balanced scorecard, which is very complex and time consuming process. To address the bottom line of the sustainability (economy, environment and social), we develope a very useful 12 cells framework to explain, understand and identify the direct and indirect contribution of green IT initiatives. Instead of adding a new perspective for the classical BSC-IT, this paper suggests to assess each of the four perspectives along the next three themes of; automate/informate, environmental benefits and social benefits. According to Zuboff (1985) the main outcomes of Information Technology (Automate /Informate) are operation and tactical benefits, and due 
the IT nature of green IT initiatives it is implemented as a one of the strategic themes of the framework. Since the economical aspect of the sustainability is intrinsically included into the scorecard perspective We add the environmental and social benefits to have more global outcomes.

\begin{tabular}{|c|c|c|c|c|}
\hline $\begin{array}{c}\text { Auto/Info } \\
\text { Operational \& tactical benefits }\end{array}$ & $\begin{array}{l}\text { Operational } \\
\text { Excellence }\end{array}$ & Stakeholders & $\begin{array}{l}\text { Financial } \\
\text { Index }\end{array}$ & $\begin{array}{c}\text { Future } \\
\text { Orientation }\end{array}$ \\
\hline Goal & $\begin{array}{l}\text { Improve process } \\
\text { efficiency }\end{array}$ & $\begin{array}{l}\text { Meet stakeholders needs } \\
\text { more efficiently }\end{array}$ & Reduce cost & Increase productivity \\
\hline Human Capital & $\begin{array}{l}\text { - Decrease energy } \\
\text { consumptions } \\
\text {-Error/ rework } \\
\text { reductions; consistent } \\
\text { data. }\end{array}$ & $\begin{array}{l}\text {-Better customer service. } \\
\text { - Improve response time. } \\
\text {-Reduce stakeholders } \\
\text { complains, reduce error } \\
\text {-Faster data access or } \\
\text { more efficient process } \\
\text { executions. }\end{array}$ & $\begin{array}{l}\text {-Reduce use of papers, } \\
\text { tonner, energy, travels. } \\
\text {-Reduce inventory- } \\
\text { carrying cost.; Lower } \\
\text { labor cost. }\end{array}$ & $\begin{array}{l}\text { - New tools } \\
\text {-Analyze data } \\
\text { - New eco-products }\end{array}$ \\
\hline Sacial benefits & & & & \\
\hline Goal & Better work conditions & Transparency & Extra income source & Corporate culture \\
\hline Outcome & \multirow{2}{*}{$\begin{array}{l}\text {-Freeing employees' time } \\
\text { to perform value-added } \\
\text { task. } \\
\text {-Impirove work-life } \\
\text { balance. }\end{array}$} & \multirow[t]{2}{*}{$\begin{array}{l}\text {-Reporting } \\
\text {-Carbon footprint. } \\
\text {-Training. }\end{array}$} & \multirow[t]{2}{*}{$\begin{array}{l}\text {-Savings translate into } \\
\text { cost advantages for } \\
\text { clients. }\end{array}$} & \multirow[t]{2}{*}{$\begin{array}{l}\text {-Sustainable } \\
\text { organizational culture. } \\
\text {-Social culture }\end{array}$} \\
\hline $\begin{array}{c}\text { Natural Resources } \\
\text { Environment benefits }\end{array}$ & & & & \\
\hline Goal & $\begin{array}{l}\text { To optimize the } \\
\text { utilization of Green IT } \\
\text { during its lifecycle }\end{array}$ & Green organization & $\begin{array}{l}\text { Better record, easier to } \\
\text { access to funding }\end{array}$ & Awareness \\
\hline Outcome & $\begin{array}{l}\text { - Cleantech } \\
\text { - Design for environment } \\
\text { - Design for recycling } \\
\text {-Recycling and e-waste } \\
\text { - Sustainable processes }\end{array}$ & $\begin{array}{l}\text { - Reduce environmental } \\
\text { impact. } \\
\text {-Reduce carbon emission. }\end{array}$ & $\begin{array}{l}\text {-Policies (Ej, Environment } \\
\text { risk) } \\
\text {-Certifications. }\end{array}$ & $\begin{array}{l}\text {-Improve and learn. } \\
\text {-Conscience. }\end{array}$ \\
\hline
\end{tabular}

[Figure 2] Framework for Assessing Green IT initiatives

\section{Conclusions}

Radhika et al.(2011) note that no analytic framework exists to examine the potential benefits after green IT initiatives are successfully implemented and putted in use. The sustainable IT balanced scorecard 12 cells derived and presented in this paper address this gap in the green IT research literature.

In this paper, we present some ideas that can help managers and CIOs to implement green IT initiatives and by doing with the framework generate measures and cause and effect relationships. The framework also demonstrates their validity in assisting managers in their use of the IT balanced scorecard to validate the current drivers of today's IT BSC (demonstration of IT value, IT governance and cost cutting \& efficiency)

This study reveals that green IT 2.0 initiatives are growing in the IT industry, and how those initiatives can be linked with the sustainable IT balanced scorecard's dimensions. Many companies have implemented specific environmental or social management systems while linked with an economic success of the firm. So the use of the sustainable balanced scorecard as a management tool appears hopeful to integrate environmental and social management with the general management of a company. Among many initiatives, green RFID, tele-presence, paperless solutions, print efficiency, logistic management software, assets-tracking systems, $\mathrm{e}^{-}$waste management, among others, are once again at the center of these exemplary green 2.0.

In spite of the increasing availability of full-featured green IT products and services, green IT is still not fully plug-and-play. Reaping profits from green IT investments is still hard work, with many organizations struggling to get buy-in and participation from management and end-users alike. The Greening by IT initiatives are successful in large parts because the top management efforts to achieve their goals and strategies.

Another interesting fact about the initiatives is the collaboration among multiple parties, a wealth of third-party products and services has emerged to help companies jump-start green IT projects. Vendors are working to meet the needs of IT organizations seeking to capitalize on sustainable 
practices: measuring and managing data center efficiency, launching large-scale recycling efforts, taking advantage of free cooling, and going paperless. That's good news for organizations that don't have the internal technical know-how to build such systems themselves (InfoWorld, 2009).

We demonstrate through different case studies that green IT initiatives impact all the four perspectives of the IT balanced scorecard at the organizational level, and thus, they are capable of contributing to the business strategy of the firm.

On a final note, it's worthwhile to consider the wide range of organizations represented in the initiatives, from large organizations such as Procter \& Gamble and Wal-Mart to more modest-size organization such as the City of London School for Girls and the Niagara Catholic School District. The lesson is that regardless of an organization's size or industry, it can realize business and environmental benefits through green IT. Given the state of both the economy and the environment, every project can make a difference.

\section{References}

[1] Wati, J., Koo, C., "An Introduction to the Green IT Balanced Scorecard as a Strategic IT Management System", Proceeding of the 44th Hawaii International Conference on System Sciences, pp. 1-10, 2011.
[2] Zuboff, S., "Automate/Informate: the two faces of intelligent technology", Organization Dynamics 14(2), pp. 5-18, 1985

[3] Graeser, V., Willcocks, L., Pisanias, N., Developing the IT Scorecard, 1998. Business Intelligence, 1998.

[4] Chand, D., "A balanced scorecard based framework for assessing the strategic impacts of ERP systems", Computer in Industry, 2005(56), pp. 558-572.

[5] Radhika, P., Benbunan-Fich, R., Mohan, K., "Accessing Green IT Initiatives Using the Balanced Scorecard", IEEE Computer Society, IT Pro, 2011.

[6] InfoWorld. 2009. "Green IT leader of 2009", http://www.infoworld.com/d/green-it/green-it-le aders $-2009-050$ ?page $=0,1$.

[7] Kaplan, R, Norton, D. Balanced Scorecard Diagnostics, Maximum performance, John Wiley \& Sons, Inc., 2006.

[8] Grembergen, V., Saull, R., "Linking the IT balanced scorecard to the business objectives at a major Canadian financial group”, JITCA, 2001.

[9] Grembergen V., "Monitoring the IT process through the balanced scorecard", Proceeding of 9th IRMA Conference, Boston, 1998.

[10] Bose et al., "The Green Potential of RFID Projects: A Case-Based Analysis", IEEE Computer society, 2011.

[11] Cram, A., "The IT Balanced Scorecard Revisited", Information system control journal, 2007(3), pp. 1-5.

\section{저 자 소 개}

\section{박 정 선}

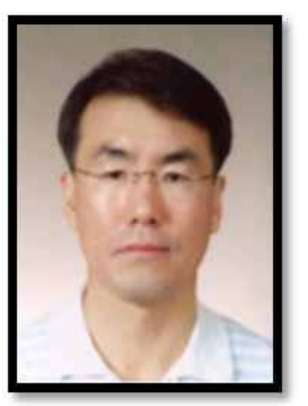

서울대학교에서 학사, 한국과학 기술원에서 석사학위를 취득하였 고, 미국 텍사스주립대학교 경영 학박사를 취득하였으며, 현재는 명지대학교 산업경영공학과 교수 로 재직중이다. 연구분야는 $\mathrm{BSC}-\mathrm{IT}$, Green IT, 정보 보안 등

주소: 경기도 용인시 처인구 남동 명지대학교 공학관 507호
Luis Ruiz

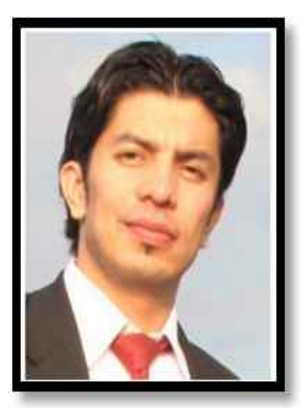

From Bogota Colombia, bachelor degree in electronics and telecommunications engineer, with a Master in Industrial and Management engineer (Myongi University). Interested in BSC, green Information Technology, etc.

Seoul, Yonsang-gu, Yonsagan 2-ga dong, 43-8 